\title{
PARTISIPASI ORANG TUA DAN TOKOH MASYARAKAT DALAM PENDIDIKAN ANAK USIA DINI (PAUD) TUNAS INSPIRATIF DI DESA CIHAMPELAS KECAMATAN CIHAMPELAS KABUPATEN BANDUNG BARAT
}

\author{
${ }^{1}$ Siti Rochana, ${ }^{2}$ Megi Rahma Bungsu \\ 1,2IKIP SILIWANGI \\ 1sitirochana94@gmail.com
}

\begin{abstract}
ABSTRAK
Pendidikan Anak Usia Dini (PAUD) adalah pendidikan yang paling mendasar dalam membangun sumber daya manusia. Partisipasi orang tua dan tokoh masyarakat setempat adalah kunci awal dalam penyelenggaraan pogram yang terdapat pada lembaga PAUD. Penelitian ini bertujuan untuk mengetahui keiikutsertaan masyarakat dalam pelaksanaan program PAUD Tunas Inspiratif Desa Cihampelas. Metode yang digunakan dalam penelitian ini adalah deskriptif dengan berdasarkan fakta hasil di lapangan. Teknik pengumpulan data yang digunakan adalah teknik wawancara dan dokumentasi dengan 2 orang tokoh masyarakat dan 3 orangtua siswa untuk membantu peneliti memperoleh data yang diperlukan. Hasil dari penelitian ini menunjukan bahwa partisipasi orang tua dan tokoh masyarakat terhadap pendidikan anak usia dini menunjukan peningkatan yang cukup baik. Hal ini didorong oleh pemahaman pentingnya pelaksanaan pendidikan pada anak usia dini. Partisipasi mereka ditunjukkan dalam bentuk kemitraan dengan lembaga PAUD Tunas Inspiratif serta terlibat aktif bersama tenaga pendidik dan pengelola PAUD sebagai pendukung untuk mencapai tujuan pendidikan sekaligus sebagai penerima manfaat dari pendidikan itu sendiri. Bentuk lainnya diantaranya ialah menjadi motivator untuk para orang tua, dan ikut berusaha meningkatkan mutu pendidikan di PAUD Tunas Inspratif.
\end{abstract}

Kata Kunci: Pendidikan Usia Dini, Masyarakat, Mutu Pendidikan

\section{PENDAHULUAN}

Suatu lembaga pendidikan merupakan tempat untuk memperoleh pengetahuan dan keterampilan yang diterima oleh masyarakat tertentu. Di sisi lain, pembangunan bangsa adalah implementasi proses yang diarahkan untuk mengkomposisi kembali lembagalembaga negara sehingga mereka dapat mencerminkan keinginan, kebutuhan, dan aspirasi masyarakat yang lebih luas. Pendidikan merupakan prasyarat penting bagi pembangunan bangsa karena semakin banyak orang yang menjadi tercerahkan semakin mereka menahan diri dari melakukan praktik yang akan membahayakan upaya pembangunan bangsa. Saat ini kita hidup di dunia dengan perkembangan informasi dan pengetahuan yang sangat pesat sehingga menempatkan pendidikan pada posisi paling penting bagi setiap keluarga, komunitas, dan bangsa. Kita harus menjaganya dan 
mengembangkannya untuk pembangunan sosial ekonomi. Kualitas pendidikan berarti pertumbuhan dan perkembangan intelektual, emosional, spiritual, dan sosial.

Pendidikan adalah bagian penting dalam sebuah kemajuan bangsa. Maju atau mundurnya sebuah bangsa tergantung sejauh mana tata kelola pendidikan bangsa negara tersebut. Pendidikan dalam pelaksanaannya menjadi tanggung jawab bersama yang dilaksanakan oleh seluruh komponen bangsa dan negara. Dalam keberlangsungannya masyarakat sejak lama telah berkontribusi signifikan merintis dan mengembangkan pendidikan di tanah air. Lembaga pendidikan, baik yang di bawah naungan komunitas sosial, organisasi masyarakat maupun yayasan telah memberikan sumbangan dalam membangun bangsa dan negara dengan jalur pendidikan.

Masa kanak-kanak adalah tahap kehidupan yang sangat penting dalam hal perkembangan fisik, intelektual, emosional dan sosial seorang anak. Perubahan terjadi pula pada softskills anak mengenai kemampuan berpikir dan berbicara yang lebih rumit pada lingkungan heterogen (Firmansyah, 2018). Pertumbuhan kemampuan mental dan fisik berkembang pada tingkat yang mencengangkan dan proporsi pembelajaran yang sangat tinggi terjadi sejak lahir hingga usia enam tahun. Ini adalah saat ketika anak-anak sangat membutuhkan pelayanan pribadi dan pengalaman belajar yang berkualitas tinggi. Pendidikan tersebut dimulai dari saat anak dilahirkan dan berlanjut ketika anak mulai menghadiri lingkungan anak- anak sebaya. Kemampuan belajar manusia terus berlanjut selama sisa hidup mereka tetapi tidak pada intensitas yang ditunjukkan di tahun-tahun prasekolah. Dengan demikian bayi dan balita memerlukan pengalaman belajar awal yang positif untuk mendorong perkembangan intelektual, sosial dan emosional mereka dan ini meletakkan dasar untuk kesuksesan sekolah di kemudian hari.

Partisipasi masyarakat dalam mengembangkan program Pendidikan Anak ussia dini ialah suatu upaya mengikutsertakan masyarakat dalam perencanaan, pelaksanaan dan pengawasan serta monitoring dan evaluasi pendidikan. Hal ini sesuai dengan UU Sisdiknas Nomor 20 Tahun 2003, pasal 8 yang menyatakan bahwa masyarakat berhak berperanserta dalam perencanaan, pelaksanaan, pengawasan dan evaluasi program pendidikan. Partisipasi masyarakat dalam mengembangkan program pendidikan ini diharapkan mampu meningkatkan mutu pendidikan secara menyeluruh yang berakhir pada peningkatan mutu sumber daya manusia Indonesia.

Desa Cihampelas termasuk desa yang minim sumber daya manusia (SDM). Umumnya masyarakat yang menempati wilayah seluas 469 Ha ini hanya lulusan SLTP dengan tingkat penghasilan yang rendah. Hal ini diperparah dengan fasilitas kesehatan yang masih kurang memenuhi kebuuhan masyarakat yang berjumlah 17.842 jiwa (Data Monografi Desa Cihampelas, 2016). Hal ini menjadi tantangan tersendiri dalam sosialisasi dan peningkatan kualitas pendidikan anak ussia dini seperti yang dikehendaki oleh pemerintah. Sadar akan hal tersebut tokoh masyarakat di lingkunga Desa Cihampelas terpanggil untuk mendirikan lembaga pendidikan yang khusus menyelenggarakan kegiatan pendidikan usia dini dengan harapan dapat memberikan sumbangan pada peningkatan SDM di lingkungan setempat. Hal tersebut tidak hanya melibatkan aspek- aspek pendidikan normatif semata, melainkan juga menuntut kesadaran dan partisipasi masyarakat untuk mencapai tujuan- tujuan lembaga tersebut karena sudah barang tentu bahwa nanti masyarakat sendirilah yang akan menikmati hasil dari pendidikan yang diselenggarakan. Di sini lah titik strategis 
pelibatan masyarakat untuk mendirikan dan mengembangkan pendidikan usia dini di lingkungannya sendiri.

\section{KAJIAN TEORI}

Pada era sekarang pendidikan di Indonesia sedang dihadapi tiga tantangan besar. Pertama, sebagai akibat dari krisis global yang melanda dunia ketiga, termasuk Indonesia, menuntut pendidikan untuk berubah menyesuaikan diri dengan perkembangan masyarakat dunia. Kedua, mengantisipasi perubahan tersebut pendidikan dituntut untuk menyiapkan sumber daya manusia yang mampu bersaing pada era globalisasi. Ketiga, sejalan dengan berlakunya otonomi daerah, dengan maksud untuk memaksimalisasi potensi daerah demi kepentingan bersama, perlu dilakukan perubahan dan penyesuaian arah pendidikan nasional sehingga dapat mewujudkan proses pendidikan yang demokratis, memperhatikan keragaman dan keadaan daerah, yang pada akhirnya mendorong partisipasi masyarakat. Namun demikian, pada prakteknya lembaga pendidikan seringkali mendapat kritikan yang serius. Disinyalir sekolah selama ini menjadi alat penjinakan yang memanipulasi perserta didik agar mereka dapat diperalat untuk melayani kepentingan kelompok yang berkuasa.

Dari uraian singkat tersebut nampak jelas betapa pentingnya keterlibatan masyarakat dalam pendidikan sehingga diharapkan terjadinya proses pendidikan yang demokratis, bisa menghargai keragaman, dapat meningkatkan kompetensi sumberdaya manusia, menggali potensi yang ada di daerah, sekaligus pendidikan menjadi pemersatu bangsa. Semakin berkurangnya pembatas antar kelompok sosial dan pemerkuatan keinginan masyarakat menjadi bagian dari puncak keberhasilan pendidikan. Oleh karena itu pendidikan seharusnya tidak hanya terjadi pada ruang- ruang formal saja, melainkan juga terjadi dalam setiap tempat dan kesempatan. Hal ini yang kemudian menjadi salah satu dasar dari konsep pendidikan luar sekolah.

Pendidikan Luar Sekolah adalah setiap kesempatan berkomunikasi yang terencana di luar sekolah di mana seseorang mendapatkan informasi, pengetahuan, latihan maupun bimbingan sesuai dengan perkembangannya dengan tujuan mengembangkan keterampilan, sikap dan nilai-nilai yang menjadikannya personal yang efektif dan efisien di keluarga, profesi, dan masyarakat. Adapun (Adikusumo, 2000) dikutip Djuju Sudjana pendidikan luar sekolah merupakan pendidikan yang terorganisir di luar sistem pendidikan formal serta direncanakan supaya diikuti oleh seluruh sasaran didik dalam rangka mencapai tujuan yang telah ditetapkan serta proses pendidikannya pun tidak jenjang atau dimensi tertentu dimana pendidikan disesuaikan dengan kebutuhan masyarakat yang sifatnya mendesak.

Adapun jenis-jenis Pendidikan Luar Sekolah yang terdapat di Indonesia adalah Pendidikan Orang Dewasa, Pendidikan Anak usia dini, Pendidikan Life Skills, Pendidikan Kesetaraan, Pendidikan Seumur Hidup, dan Pendidikan Keaksaraan. Berkaitan dengan pendidikan anak usia dini sebagai salah satu bentuk Pendidikan Luar Sekolah sesungguhnya telah diatur dalam UU Sisdiknas pasal 1 ayat 14 Nomor 20 tahun 2003. Negara sangat serius memperhatikan kegiatan pendidikan anak ussia dini karena kelak pendidikan jenis ini akan menjadi dasar sekaligus bekal bagi anak untuk melanjutkan pendidikan ke jenjang berikutnya.

Pendidikan seharusnya menjadi kunci bagi sebuah kemajuan bangsa. Tanpa pendidikan yang baik sebuah bangsa dan negara tidak akan maju dan berkembang dengan baik. Dalam konteks keberlangsungannya, pendidikan tidak hanya dirintis dan dilaksanakan oleh pemerintah, akan tetapi masyarakat dari sejak dahulu telah menunjukan peran 
besar dalam merintis dan melaksanakan pendidikan di tanah air. Bahkan jauh sebelum kemerdekaan lembaga pendidikan baik yang di bawah naungan komunitas sosial, ormas maupun yayasan telah bekerja sama untuk membangun bangsa dan negara melalui pendidikan.

Keterlibatan masyarakat dalam mengembangkan Pendidikan Anak usia dini merupakan usaha melibatkan mereka dalam proses penyelenggaraan pendidikan dari mulai perencanaan hingga mengevaluasi pendidikan. Hal ini berarti bahwa masyarakat ikut terlibat dalam keputusan dengan bentuk penyampaian saran dan pendapat. Partisipasi dapat juga bermakna bahwa masyarakat mengenal masalah mereka sendiri, memecahkan masalahnya, mengkaji pilihan mereka, dan mengambil keputusan. Keterlibatan masyarakat dalam mengembangkan. Pendidikan Usia Dini pada gilirannya akan melahirkan rasa memiliki dan tanggungjawab masyarakat terhadap kemajuan pendidikan itu sendiri dan sekaligus menjadikan masyarakat sebagai salah satu pusat pendidikan.

Tilaar berpendapat (Tilaar, 1999) bahwa partisipasi dalam perkembangannya memiliki pengertian yang beragam. Dalam kultur demokratis setidaknya terdapat tiga tradisi partisipasi, yaitu partisipasi politik, partisipasi sosial dan partisipasi masyarakat. Sedangkan partisipasi masyarakat diartikan sebagai keterlinatan masyarakat dalam pembuatan kebijakan dan pengambilan keputusan di berbagai dimensi yang akan mempengaruhi kehidupan mereka. Bentuk-bentuk partisipasi tersebut menurut Sastroputro (Sastropoetro, 1989) membagi 5 bentuk partisipasi, yaitu (1) Partisipasi buah pikiran, (2) Partisipasi keterampilan, (3) Partisipasi tenaga, (4) Partisipasi uang, dan (5) Partisipasi harta benda. Penyelenggaraan pendidikan bukan hanya tugas bagi pemerintah semata, akan tetapi masyarakat memiliki andil dalam memajukan pendidikan. Hal itu diperkuat dalam UU Sisdiknas Nomor 20 Tahun 2003, Pasal 8 yang menyatakan bahwa masyarakat berhak terlibat dalam perencanaan, pelaksanaan, pengawasan, dan evaluasi program kerja di bidang pendidikan. Pasal berikutnya menyatakan bahwa masyarakat berkewajiban memberikan dukungan sumber daya dalam penyelenggaraan pendidikan.

\section{METODE}

Metode penelitian yang penulis gunakan pada penelitian ini menggunakan metode penelitian deskriptif dengan menggunakan pendekatan kualitatif (Sugiyono, 2014). Metode penelitian kualitatif adalah metode penelitian yang berlandaskan pada filsafat postpositivme, digunakan meneliti pada kondisi objek yang alamiah, (sebagai lawannya adalah eksperimen) dimana peneliti adalah sebagai instrumen kunci, teknik pengumpulan data di lakukan secara triangulasi (gabunga), analisis data bersifat induktif/ kualitatif, dan hasil penelitian kualitatif lebih menekankan makna dari pada generalisasi.

Lokasi peneletian ini dilakukan di lingkungan PAUD Tunas Inspiratif Desa Cihampelas Kecamatan Cihampelas Kabupaten Bandung Barat. untuk teknik pengumpulan data yang penulis gunakan adalah teknik wawancara dan dokumentasi dengan 2 orang tokoh masyarakat dan 3 orangtua siswa untuk membantu peneliti memperoleh data yang diperlukan dalam melakukan penelitian. 


\section{HASIL DAN PEMBAHASAN}

\section{Hasil}

Pemahaman masyarakat tentang anak usia dini yaitu anak usia dini merupakan anak usia prasekolah yang pelu dibimbing dan diarahankan oleh orangtua. Anak usia dini merupakan usia anak yang sangat memerlukan perhatian dan kasih sayang dari orangtua untuk menumbuhkan bakat dan mengembangkan potensi yang dimilikinya. Anak usia dini ialah peniru terbaik. Oleh karena itu mereka perlu diberikan contoh dan bimbingan yang terbaik dari keluarga dan lingkungannya.

Pendidikan Anak usia dini merupakan pendidikan yang wajib diberikan kepada anak sehingga anak dapat menjadi terampil dan tumbuh dengan baik. Pendidikan anak usia dini diberikan dengan cara bermain yang menyenangkan sambil belajar dan bersosialisasi sehingga diharapkan anak dapat mengembangkan potensinya dengan sempurna dan mampu hidup bersama dengan lingkungan sosialnya. Selain itu pendidikan anak usia dini harus dilaksanakan secara tepat sebagai bekal awal untuk melanjutkan ke jenjang pendidikan selanjutnya.

Pelaksanaan pendidikan anak usia dini di rumah orangtua membiasakan berbagai hal kepada anak sejak bangun tidur hingga tidur lagi. Anak sudah dibiasakan tidur lebih awal agar durasi tidur ideal tercapai untuk menjagakesehatannya. Membiasakan anak untuk bangun dan melaksasnakan aktifitas bersama orangtuanya sebelum berangkat ke sekolah lalu orang tuanya mengantarkan ke sekolah. selain itu orang tua mengajarkan anak bernyanyi, membaca doa pendek, mengucap salam dan mencium tangan orang yang lebih tua. Orangtua berkomunikasi dengan pengelola lembaga pendidikan anak usia dini terkait perkembangan anak didiknya, mengikuti rapat rutin, dan memberikan masukan kepada pihak pengelola demi majunya lembaga pendidikan tersebut. Orangtua juga ikut mengamati selama proses pembelajaran di PAUD sambil menunggu waktu pulang. Mereka senantiasa menemani sambil mengamati perilaku anak sewaktu di rumah, mengajak anak untuk bermain saat tidak ada temannya. Mereka juga mengevaluasi kegiatan di PAUD Tunas Inspiratif dengan menanyakan aktivitas selama disana, melakukan pengulangan di rumah terhadap apa yang dilakukan di PAUD dan bertukar cerita dengan pengelola atau guru terkait hambatanhambatan ketika anak belajar. Dalam kondisi tertentu sebagian orangtua terlambat membayar uang sekolah keuangan sedang minim. Walaupun kondisi uang sedang minim, orangtua telah menyisihkan uangnya untuk anak sehingga tetap tetap waktu membayarnya. Membayar tabungan wajib tiap bulan, memberikan bantuan lain bersama dengan orangtua murid lainnya melalui iuran untuk kegiatan, membayar iuran untuk membeli alat peraga, dan memberikan sumbangan sukarela. Harapan orangtua agar dapat mewujudkan anak didik yang sehat, terampil, cerdas dan berkarakter, serta bisa menjadi tahap awal untuk melanjutkan ke jenjang berikutnya. Secara khusus bentuk- bentuk partisipasi tokoh masyarakat yaitu memberikan motivasi kepada masyarakat untuk melaksanakan pendidikan usia dini di rumah dan di lembagalembaga pendidikan anak usia dini. Selain itu masyaakat terlibat dalam peningkatan mutu pendidikan di PAUD Tunas Inspiratif.

\section{Pembahasan}

Orang tua memang menjadi pengaruh utama dalam pengalaman belajar dan pendidikan anak. Apapun yang dilakukan orang tua sangat berdampak pada anak-anak mereka pada perkembangan selanjutnya. Orangtua terkadang lupa bahwa orang tua memiliki 
dampak yang luar biasa terhadap pendidikan anak-anak pada usia berapapun. Jika orang tua memilih untuk berpartisipasi dalam kelompok Ibu dan Balita atau lembaga pendidikan anak usia dini, memiliki potensi untuk memberikan pengalaman berkualitas tinggi, individual, responsif, dan rangsangan yang akan mempengaruhi pengalaman belajar anak. Hubungan yang sangat kuat tertanam dalam rutinitas sehari-hari yang disediakan oleh lembaga pendidikan anak usia dini menjadi utama dalam kehidupan anak. Termasuk sejak anak masih berada di lingkungan keluarga, penanaman nilai-nilai kehidupan menjadi sangat penting untuk membentuk karakter anak di masa yang akan datang (Akhyadi \& Mulyono, 2018).

Keterlibatan keluarga sangat diperlukan dalam pendidikan anak usia dini. Hal ini disebabkan oleh proses awal anak belajar dimulai dari lingkungan keluarga. Pendidikan anak usia dini sebagai aspek penting dalam rencana pembangunan sumber daya manusia Indonesia menjadi fundamental dan signifikan bagi pembangunan. Oleh karena itu kewajiban orang tua untuk terlibat didalam pertumbuhan dan perkembangan anak sangat diperlukan.

Penelitian ini menunjukan bahwa kesadaran dan pemahaman masyarakat terhadap pendidikan anak usia dini telah membaik. Dapat diperoleh gambaran dalam pandangan oang tua bahwa anak usia dini adalah anak di bawah usia enam tahun yang perlu diberikan perhatian dan kasih sayang serta dibimbing oleh orangtua sehingga anak tumbuh dan berkembang dengan baik. Meskipun pendapat masyarakat bermacammacam namun mereka cukup memahami tentang anak usia dini. Proses pembiasaan yang dilakukan di rumah sejak dini akan terbawa hingga mereka dewasa.

Berdasarkan hasil penelitian ini menunjukan bahwa para orangtua di Desa Cihampelas umumnya telah mengenalkan dan mengajarkan anaknya agama sejak dini. Hal tersebut dilakukan dengan mengajarkan dan membiasakan anaknya untuk berdoa sebelum melakukan aktivitas rutin harian mereka, mengucap salam dan juga mencium tangan orang yang lebih tua. Para tokoh masyarakat juga ikut serta dalam upaya meningkatkan mutu di PAUD Tunas Inspiratif. dengan ikut serta dalam kegiatankegiatan yang dilaksanakan di lembaga pendidikan anak usia dini.

\section{KESIMPULAN}

Partisipasi orang tua dan tokoh masyarakat terhadap lembaga menunjukan tingkat yang cukup baik. Hal tersebut didorong oleh pemahaman mereka terhadap pentingnya pelaksanaan pendidikan anak usia dini di daerah tersebut. Ikut serta mereka dalam penyelenggaraan PAUD Tunas Inspiratif Desa Cihampelas Kecamatan Cihampelas Kabupaten Bandung Barat dilakukan dalam bentuk mitra kerja yang aktif, menjadi penghubung PAUD Tunas Inspiratif dengan rumah, selain itu menjadi penyongkong PAUD Tunas Inspiratif untuk mencapai prestasi pendidikan yang unggul, terlibat aktif bersama tenaga pendidik dan pengelola PAUD, sebagai pendukung tujuan pendidikan, dan sebagai penerima pendidikan. Bentuk lainnya diantaranya ialah menjadi motivator untuk para orang tua, dan ikut meningkatkan mutu PAUD Tunas Inspiratif. Adapun kendala yang dihadapi diantaranya menyangkut persoalan pembiayaan yang masih terbatas sehingga fasilitas dan media belajar masih kurang dan perlu di lengkapi. Adapun kendala yang dihadapi PAUD Tunas Inspiratif diantaranya menyangkut persoalan pembiayaan yang masih terbatas, fasilitas dan media belajar yang masih perlu dilengkapi, dan tenaga pendidik masih ada yang belum memenuhi standar pendidik PAUD. 
Dari simpulan penelitian ini penulis dapat merekomendasikan beberapa hal, baik kepada lembaga pendidikan anak usia dini Tunas Inspiratif maupun kepada masyarakat setempat, yakni hendakanya pengelola dapat menggali sumber-sumber anggaran pembiayaan PAUD secara kreatif sehingga seluruh kebutuhan pelaksanaan dan peningkatan mutu pendidikan bisa terpenuhi secara memadai. Lalu dalam melengkapi fasilitas dan media belajar hendaknya mampu memanfaatkan sumber daya yang ada di daerah setempat. PAUD Tunas Inspiratif bisa membuat sendiri fasilitas dan media belajar dari bahan-bahan yang terdapat di lingkungan PAUD berdiri yang tentu akan dapat menghemat biaya pengiriman dan produksi. Mendorong tenaga pendidik untuk melanjutkan kuliah agar kualifikasi pendidik dapat terpenuhi. Peran penting masyarakat dalam sistem pendidikan PAUD diantaranya untuk mengatasi masalah manajemen seperti dalam proses penilaian dan hasil pembelajaran di sekolah.

\section{DAFTAR PUSTAKA}

Adikusumo, S. (2000). Pendidikan Luar Sekolah Wawasan Sejarah Perkembangan Falsafah \& Teori Pendukung Asas. Bandung: Nusantara Press.

Akhyadi, A. S., \& Mulyono, D. (2018). program parenting dalam meningkatkan kualitas pendidikan keluarga. Abdimas Siliwangi, 1(1), 1-8.

Ansori, A \& Samsudin, A. (2013). TRANSFORMASI PEMBELAJARAN DI PENDIDKAN NON FORMAL (Upaya mempersiapkan pendidik dan peserta didik dalam menghadapi tantangan global untuk menjadi manusia pembelajar). Empowerment, 2 (1), 1-15

Firmansyah, D. (2018). Analysis of Language Skills in Primary School Children (Study Development of Child Psycology of Language), 35-44.

Sastropoetro, S. (1989). Partisipasi Komunikasi, Persuasi dan Disiplin Dalam Pembangunan Nasional. Bandung: Alami Press.

Sugiyono. (2014). metode penelitian kuantitatif kualitatif dan R\&D. Bandung: alfabeta.

Tilaar, H. A. (1999). Pendidikan, Kebudayaan, dan masyrakat madani Indonesia. Bandung: PT Remaja Rosdakarya. 